\title{
Planctus Mariae: Performing Compassion as a Means of Social Promotion
}

Eliška Poláčková

\begin{abstract}
Summary
The aim of the study is to explore the emancipative potential of performative practices associated with the high medieval idiom of affective devotion, particularly with the genre of Marian Lament (planctus Mariae). The mechanisms of (temporal) social elevation through a bodily experience of such cultural motives as Christ's Bride (sponsa Christi), Tools of Christ's Passion (arma Christi) and the veneration of Christ's Side Wound are demonstrated on the example of the Planctus Mariae in the Passional of Abbess Kunigunde, a $14^{\text {th }}$-century manuscript codex produced in Bohemia for the eponymous abbess of the Benedictine nunnery of St. George at the Prague Castle.
\end{abstract}

\section{Key words}

Marian Planct, Marian Lament, Planctus Mariae, Passional of Abbess Kunigunde, medieval literary performance 
In this work, I would like to explore a piece of High-Medieval Bohemian literature, the fourteenth-century Latin Lament of the Virgin Mary extant in a manuscript codex known as the Passional of Abbess Kunigunde. ${ }^{1}$ The research goal is to assess the performative potential of the text, especially as a means of (at least) temporary social elevation. I would argue that performing the Planct as a form of devotional practice - which is what the text was originally intended for - might have produced not only deep and profound sense of religious elation, but also a sense of being elevated in terms of social and moral status. This was likely especially true for female devotees who read and/or performed the Lament as a part of their spiritual meditation in convents or in secular congregations such as those of the Beguines. ${ }^{2}$

I have elsewhere presented a detailed discussion of the genre of Marian Lament and the Lament of the Virgin Mary from the Passional (POLÁC̆KOVÁ 2021); here, I consider the Lament as a devotional performance script, to borrow a term from Sarah McNamer, informed by a particular medieval religious practice called 'affective piety'. In the Middle Ages, affective piety referred to texts, artefacts, discourses, ideologies and performative practices the objective of which was to relate the narrative of Jesus Christ's death on the Cross to the personal experience of Christian believers. ${ }^{3}$ This drawing a powerful link between the heavenly and earthly sphere, the primary purpose of this ideological formation was to preach important doctrinal points with greater immediacy and persuasiveness to specific groups of the medieval faithful - religious women and (aristocratic) laity. The poetic mechanism behind this set of texts and performative practices pertained to the human body and its sensations. The ultimate goal of affective devotional practices, such as compassion for Christ's suffering (compassio Christi), was to make believers feel the same emotions as did Christ and to imagine oneself standing at the cross alongside the Virgin Mary and experiencing the grief of the mother of Christ as if it was their own (compassio Mariae; cf. SHOEMAKER 2001).

As the fourteenth-century German theologian Ludolf of Saxony puts it, the devotee 'must make herself or himself as one with what was said or done by Christ the Lord $[\ldots]$ as if [they] heard it with [their] own ears and saw it with [their] own eyes' and he or she 'should meditate on all of them as if they were present'. ${ }^{4}$ What follows in Ludolf's meditational tract strikes one as a description of an ideal Stanislavski's exercise for actors, instructing the devotee to recite the respective sections of Christ's passion, pull one's hair and scratch one's forehead when he was crowned by the crown of thorns, kneel when he

\footnotetext{
1 Ms. XIV A 16, National Library Prague, the planct on fol. 11r-17v, accessible from www.manuscriptorium. com, where the detailed information about the manuscript can be found.

2 See the chapter 'Religious Life: Beguines, Penitents and Recluses' in (WARD 2002). - For a detailed discussion of the manuscript, especially its primary (Abbess Kunigunde) and implied (the nuns of the convent of St. George in Prague) readers, see (POLÁČKOVÁ 2021).

3 See especially (MCNAMER 2010: 24-117); here also further reading.

4 Orig.: 'Tu autem [...] ita praesentem te exhibeas, his quae per Dominum Jesum dicta vel facta sunt, et ex his quae narrantur, ac si tuis auribus audires, et oculis videres [...] tu tamen omnia tamquam in praesentia fierent, mediteris' (IOHANNIS DE CAULIBUS, Meditationes vitae Christi, 10; transl. CONWAY 1976, 124). English translations are the author's unless indicated otherwise.
} 
knelt when he could no longer bear the weight of the Cross, and laying prostrate on the ground when Virgin Mary fainted at the sight of her Son nailed to the Cross.

I believe it can be argued that such corporeal and empathizing devotional practices placed the medieval believer in a position similar to that of Stanislavski's actor who tries to get as close to the character (here Jesus Christ and Virgin Mary) as possible when performing, i.e. experiencing the emotions and meanings of the character through his/her own body. ${ }^{5}$ Like theatre actors, medieval believers were invited to participate in the execution of this and similar devotional practices, and to use their empathy and creativity to perform, ruminate and expand on their capacity to understand and communicate with the divine. ${ }^{6}$

In the limited space of this article, I would like to develop this argument likening a medieval devotee's handling of sacred objects during acts of affective meditation to a particular aspect of actor's work in terms of interactions with props and other material objects (s)he may have at her/his disposal in theatrical performance. In case of affective devotional practices, the 'affective props' would comprise books (manuscript codices), rolls, reliquaries, amulets, textiles, and other devotional objects employed during the performance of affective piety. The common denominator of all the devotional practices was meditation over the text accompanied by physical interaction with a devotional object: the devotee was encouraged by the text, implicitly or explicitly, to touch, carry, heave, caress or kiss these objects to grasp and experience the meanings of the text with greater depth and intensity. ${ }^{7}$

\section{Compassio Mariae: Becoming Virgin Mary by Gazing at and Reading Jesus Christ}

Two objects related to the Lament of the Virgin Mary from the Passional of Abbess Kunigunde will be discussed in this context: the bloody veil of the Virgin Mary and the image of the Tools of Christ's Passion (arma Christi) depicted in the manuscript.

The peplum cruentatum, or bloody veil of the Virgin Mary, is first mentioned in the twelfth-century Rhymed Life (Vita rhytmica), a verse biography of the Virgin Mary:

Having embraced the bloodied stem of the Cross

And having been reddened by her son's blood from her head to feet,

$5 \quad$ Konstantin Stanislavski invented an acting technique referred to as the 'magic if'. The phrase denotes a strategy according to which actors are encouraged to start their work by asking 'What would I do if I were in this situation?' (STANISLAVSKI 2003 [1936]: 65).

6 For the analogies between social and theatrical acting, see e.g. (WALSH-BOWERS 2006).

7 An interesting point in this debate is Andrew Sofer's discussion of the bloody handkerchief so often used on the Elizabethan stage. He traces its origin back to medieval liturgical performances in which it represented the death and resurrection of Jesus Christ (SOFER 2003: 63-75). On a larger scale, Sofer's book presents a number of persuasive arguments explaining the role of objects in both aesthetic and cultural performances. 
She kissed the blood that poured from Jesus's body

And dripped from his wounds to the ground. ${ }^{8}$

The stanza depicts the Mother of God desperately clutching the base of the Cross, kissing the wood covered in her Son's blood. Of extreme importance here is the shocking detail of the Virgin Mary being literally covered with blood dripping from her Son's crucified body. ${ }^{9}$

The same motif was elaborated several decades later into the image of Mary's veil ostensibly spattered by the blood running out or spurting from Christ's side. Several depictions of Christ's blood dripping onto the head of his mother can be found in High-Medieval European painting, mostly originating in Germany and Bohemia of the time. An example of this visual motif can be found on the desk painting of crucifixion from the so-called Vyšší Brod Altar (Vyšebrodský oltář) from the Cistercian monastery in Vyšší Brod. Painted around 1347, the panel in question depicts the Virgin Mary standing at the foot of the Cross and supported by John the Evangelist, while the first drops of her son's blood spatter her head (see Fig. 1). ${ }^{10}$

This image, found on many other desk altars in contemporary churches, ${ }^{11}$ has a literary parallel in the genre of Marian Laments, including the Lament of the Virgin Mary discussed here. A similar narrative situation describing Mary weeping at the death of her son at the foot of the Cross is apparent in the following extract:

He bowed like that when he, dying and falling asleep on the cross, commended his spirit in the hands of his Father. Having been carried away hereof, he was laid down in a cave of an oh-so-hard a stone, and when a stone was rolled to the door of the sepulchre, put among the dead. Behold, oh all people, and watch my pain: has ever been seen such pain as mine? Meanwhile, one of the bystanders, perhaps this John the Apostle, whom he had left to her as a consolation, speaks to her. ${ }^{12}$

The relation between the text of the Lament and the visual images of Mary weeping at the foot of the Cross would appear even more clearly if we consider the supposed

8 Orig.: 'Amplexa tamen stipitem crucis cruentatam, / Et nati sui sanguine totam rubicatam, / Osculatur sanguinem Jesu defluentem / De suis vulneribus ad terramque currentem' (Vita beatae virginis Mariae et salvatoris rhythmica, ed. Adolf Vögtlin, Tübingen, 1988, p. 169, lines 5026-5029).

9 An extensive discussion of the image of the Virgin Mary's bloodied head and its visual representations for an extensive (HAMBURGER 2011).

10 On the philosophical and religionist interpretation of the painting and the whole cycle it is part of, see (NEUBAUER 2011); general information on the altar cycle see in (PEŠINA 1982).

11 For the dissemination of the image across medieval Europe, see (NEFF 1998).

12 Orig.: 'Sic nempe ille declinaverat, quando moriens patibulo obdormiens in manus patris spiritum inclinato capite commendabat. Inde translatus, indurissimi lapidis spelunca est repositus, et ad voluto saxo ad ostium monumenti inter mortuos est locatus. Attendite igitur innumeri populi et videte dolorem meum, si, inquam, visus dolor similis sicut dolor meus. Interea dicit ei unus de circumstantibus, Johannes forsitan ille discipulus, cui eam consolandam reliquerat illic [...]'; (Narodní knihovna ČR v Praze, XIV A 17, Passionale quod dicitur Cunegundis abbatissae, fol. 11v). I thank Tomáš Weissar for cross-checking my reading of the given part of the manuscript. 


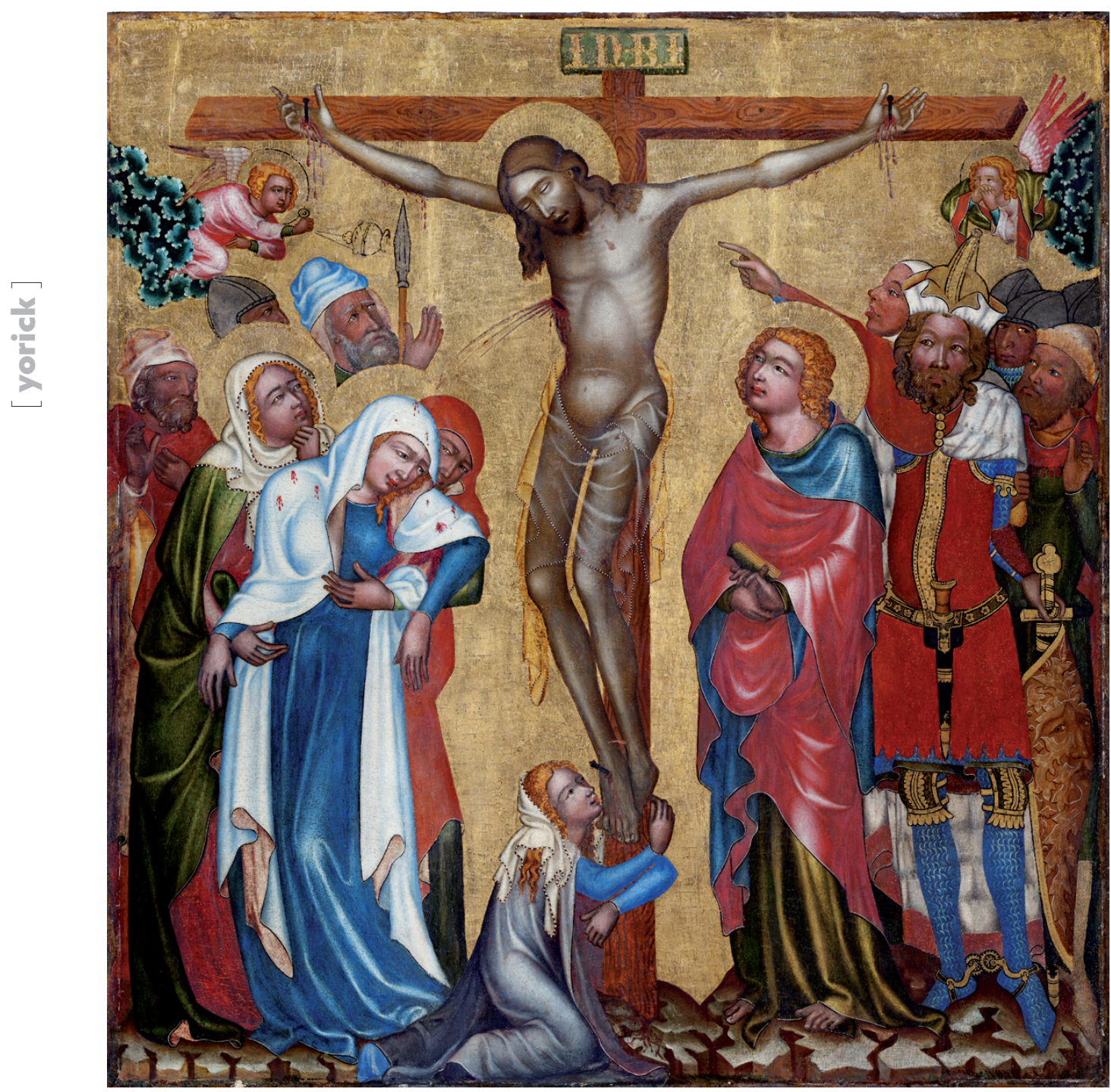

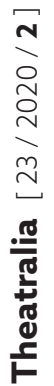

mode of the original reception of the Planct. As was already noted, the text survived as the manuscript codex called the Passional of Abbess Kunigunde (Passionale abbatissae Cunegundis). The daughter of Ottokar II of the royal Bohemian House of Přemyslid, Kunigunde had become an abbess of the Benedictine nunnery of St. George at the Prague Castle in 1302 and remained in the office for the next 20 years until her death. The manuscript was conceived for the personal use of the Abbess, and the texts in- 
cluded in it were to be read as an exercise in affective meditation either in privacy of her chambers or in the presence of other nuns of the convent. ${ }^{13}$

Either way, the meditative reading of the Lament would demand the use of certain visual aids to accompany the words and to enhance the experience of being bodily present in the situation of the crucifixion. The visual supplement might have been a desk painting in the conventual church of the nunnery similar to the Altar from Vyšší Brod discussed above, an analogous illumination in a manuscript owned by the conventual library, or a sculpture similar to the one in Fig. 2.

Similar sculptures as this one, called Křivák's Pieta after its discoverer Petr Křivák (HRBÁČOVÁ 2015), were often exhibited at church altars, on desk altars, or independently in the space of high-medieval churches. Křivák's Pieta and similar works of art may be considered yet other referential objects for affective meditational practices such as those based on the text of the Lament of the Virgin Mary. A devotee, probably a female member of the convent, might have fuelled her rumination over the feelings of the Virgin Mary expressed in the Planct by recalling images she had seen in the past or by actually gazing at a corresponding image of figure such as Křivák's Pieta, the Crucifixion from Vyšší Brod, or an illumination of a similar nature.

Alternatively, the pious nun might have related her experience of the Planct to a yet another devotional object, the actual veil of the Virgin Mary tainted by Christ's blood, or the peplum cruentatum. A number of these veils were scattered across Europe at the time of the origin of the manuscript, with, curiously, two of them located in Prague: one in the treasure of the St. Vitus Chapter, another in the Cistercian convent at Zbraslav. The credit for at least one of these invaluable acquisitions goes to Holy Roman Emperor and Czech King Charles IV, who acquired the precious relic around 1347 and entrusted it to the Metropolitan Chapter. The relic from St. Vitus Cathedral, called by Jeffrey Hamburger a 'super-relic' thanks to its immense popularity at that time (HAMBURGER 2011: 1), was kept in a crystal reliquary in the chapter treasury and was exhibited regularly during the Feast of the Spear and Nails of Our Lord together with other Passion relics at the Cattle Market, today's Charles Square (ŠRONĚK 2009). An event of extreme religious and performative appeal, the exhibition would attract thousands of people from all over Europe who gathered in Prague to admire the holy relics displayed in exquisite golden, silver and ivory cases inlaid with precious stones as well as to attend solemn liturgical services and walk in spectacular processions.

It is easy to imagine that the nuns of the St. George nunnery did not remain uninvolved in this religious feast but joined the collective euphoria and went to witness the relics for themselves. Or if they did not attend the exhibition on their own, they might at least have heard about it from someone who was actually there. One way or another, the nuns of St. George could meditate on the relic, or perhaps only its fictitious image, during their reception of the lament. Unlike in the Vita Christi by Ludolf, the empathizing manner of compassionate reading is not particularly emphasized in the Lament of

13 For general information on the Abbess Kunigunde and the Passional, see (URBÁNKOVÁ a STEJSKAL 1975). The Latin text remains unedited; see Czech translation in (VILIKOVSKÝ 1948: 41-43). 


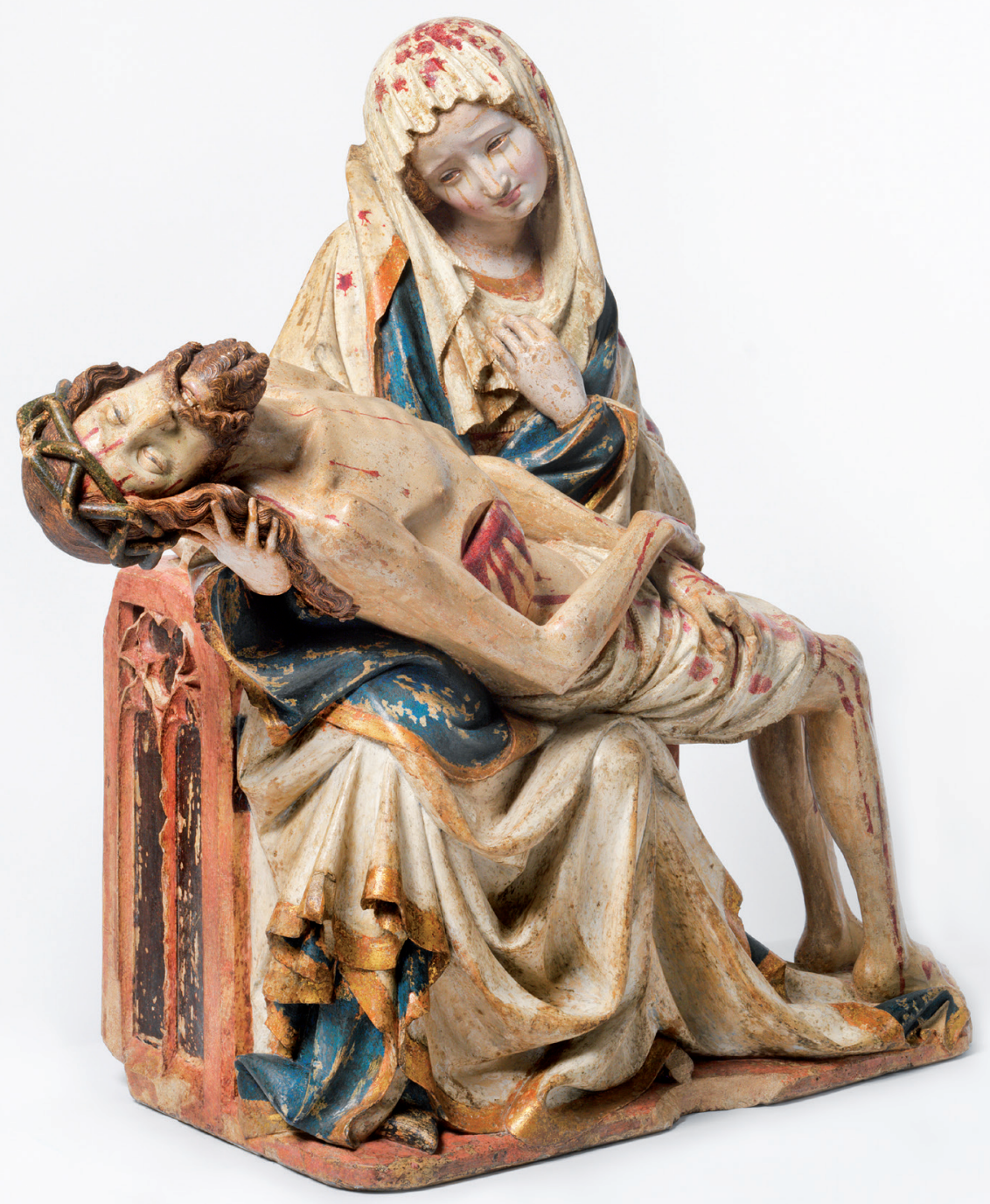

Fig. 2: Křivák's Pieta: anonymous; the Pieta from the collection of Canon Křivák, between 1390-1400; argillite, polychrome; height $74 \mathrm{~cm}$.

(c) Muzeum umění Olomouc; author: Markéta Lehečková. 
the Virgin Mary from the Passional, yet this does not necessarily mean that its affective reception was not implied. The Lament seems to fall into the same category as the other texts featured in the manuscript identified as mystical tracts, one of the typical genres of the affective devotional writing. Therefore, the Lament might have been intended to arouse the same type of compassion with the feelings of the Virgin Mary, as Ludolf suggests for the reader of the Vita Christi; correspondingly, comparable performative practices might have been apposite for its reading, i.e. empathizing with the plight of the Virgin Mary, or in Stanislavskian terms feeling or behaving as if one was the Virgin Mary. Like a modern actor, one of the effective strategies for a medieval devotee to achieve this state of being might have been watching (or contemplating) objects related to Mary's suffering, or even touching them if possible.

\section{Becoming Virgin Mary By Touching Jesus Christ, As Did His Mother}

The previous examples were meant to shed light on a specific collaboration between text and image in creating meanings in the performance of an affective meditation in which the devotee is encouraged to adopt the 'as if' position in order to liken herself/himself to the Virgin Mary witnessing the suffering of Jesus Christ. My next assertion would be that this essentially theatrical situation might sometimes have been achieved not only by gazing upon devotional objects related to the topic of the meditation, but actually touching them. I would argue for the eminent importance of sensual experience in general and tactile experience in particular in the constitution of the affective response to Christ's death and suffering, again using the Passional of Abbess Kunigunde as an example, in particular the Lament of the Virgin Mary, the text of which it includes. ${ }^{14}$

From the twelfth century onwards, the senses and sensation was considered especially important in fostering the correct meditative mood for praying in public, and maybe even more importantly in private. The capacity to experience God physically through one's own body was seen as pivotal for the intellectual apprehension of Christ as the Saviour and Redeemer of sins. This 'sensual turn' in medieval thinking is attested, for instance, in the writing of the thirteen-century theologian Bernard of Clairvaux, who speaks of Christ as 'honey in the mouth, melody in the ear', or - two centuries later in the writing of Ludolf of Saxony. ${ }^{15}$ The latter argues in the Vita Christi for a deeply sensual mode of experiencing meditative devotional literature:

If you wish to reap the fruit of your meditations, [...] then you must make yourself present at what was said or done by Christ the Lord or what is told about it, as if you heard it with your own ears or saw it with your own eyes [...]. And thus, although many of these things are told as

14 For further discussion of the tactile interaction with the Passional, see (RUDY 2018).

15 For the discussion of the role of senses in medieval thinking, see (RUDY 2002); for the role of senses in medieval culture, especially the sensual dimension of material objects of art, see (BAGNOLI 2016a). 
in the past, you should meditate on all of them as if they were in the present; because without doubt you will taste a greater pleasantness from this. Therefore, read about what was done as if it were being done. Place before your eyes past actions as if they were present, and thus to a great extent you will taste things as more savoury and delightful. ${ }^{16}$

In a similar vein, Jacob of Voragine (ca. 1230-1298) enlists the senses of touch and hearing alongside sight and taste as a way of experiencing and celebrating the memory of Christ's Passion (BAGNOLI 2016b: 27). Touch especially was of primary importance in the devotional practices connected to the affective devotion. Evocative proof of this assertion is the image of arma Christi, the tools of Christ's suffering, found in the Passional preceding the foil with the Marian Lament (Fig. 3).

This depiction is, in fact, a meticulous catalogue of the various instruments by which Christ's torments were executed, such as the scourge he was flogged with, the ladder on which he climbed the Cross, the spear that pierced his side, and the nails with which he was hammered to the Cross. ${ }^{17}$

A narrative analogy of the visual arma Christi can be found in the text of the Lament:

This body that the Spirit of God ingeniously assembled in my womb, which was so tender that it couldn't even tread the ground without pain, was lacerated by so many strokes of scourges, by so many blows of hammers and pierced by so many nails, that not a single undamaged spot can be found on it. ${ }^{18}$

As in the case of the bloody veil of the Virgin, this striking visual and narrative evocation of tools also had an analogy in the context of public religious performances. For example, on the occasion of the Feast of the Spear and Nails of Our Lord discussed in relation to the bloody veil of the Virgin Mary, the individual Tools of Passion were the central objects exhibited on the scaffolding at the Cattle Market for the pilgrims to watch and admire.

The illumination in the Passional, however, attests to a similarly performative and surprisingly corporeal devotional practice; it has been claimed that the central image of Christ's Side Wound (Fig. 4) was actually touched, even kissed by the nuns who had direct access to the manuscript and used it in their private or collective devotion

16 Orig.: 'Tu autem, si ex his fructum sumere cupis, ita te praesentem exhibeas his quae per Dominum Jesum dicta et facta narrantur, ac si tuis auribus audires et oculis ea videres [...]. Et ideo quamvis multa ex his tanquam in praeterito facta narrantur, tu tamen omnia tamquam in praesenatia fierent, mediteris; quia ex hoc majorem sine dubio suavitatem gustabis. Lege ergo quae facta sunt tamquam fiant; Pone ante oculos gesta praeterita tamquam praesentia, et sic magis sapida senties et jucunda' (IOHANNIS DE CAULIBUS, Meditationes vitae Christi, 9-10; transl. CONWAY 1976, 124); italics mine.

17 For the religious and cultural context of the Tools of Christ, as well as the individual items and their meanings, see (COOPER and DENNY-BROWN 2014).

18 Orig.: 'Illud corpusculum quod spiritus sanctus in meis visceribus illi conpegerat, quod per teneritudine nec super terram sine dolore incedere poterat, tot flagellorum ictibus dilaceratum est, tot malleorum percussionibus, clavorum quid confossionibus perforatum est, quod a planta pedis usque ad verticem, non est in eo sanitas' (Národní knihovna ČR v Praze, XIV A 17, Passionale quod dicitur Cunegundis abbatissae, fol. 12r); italics mine. 


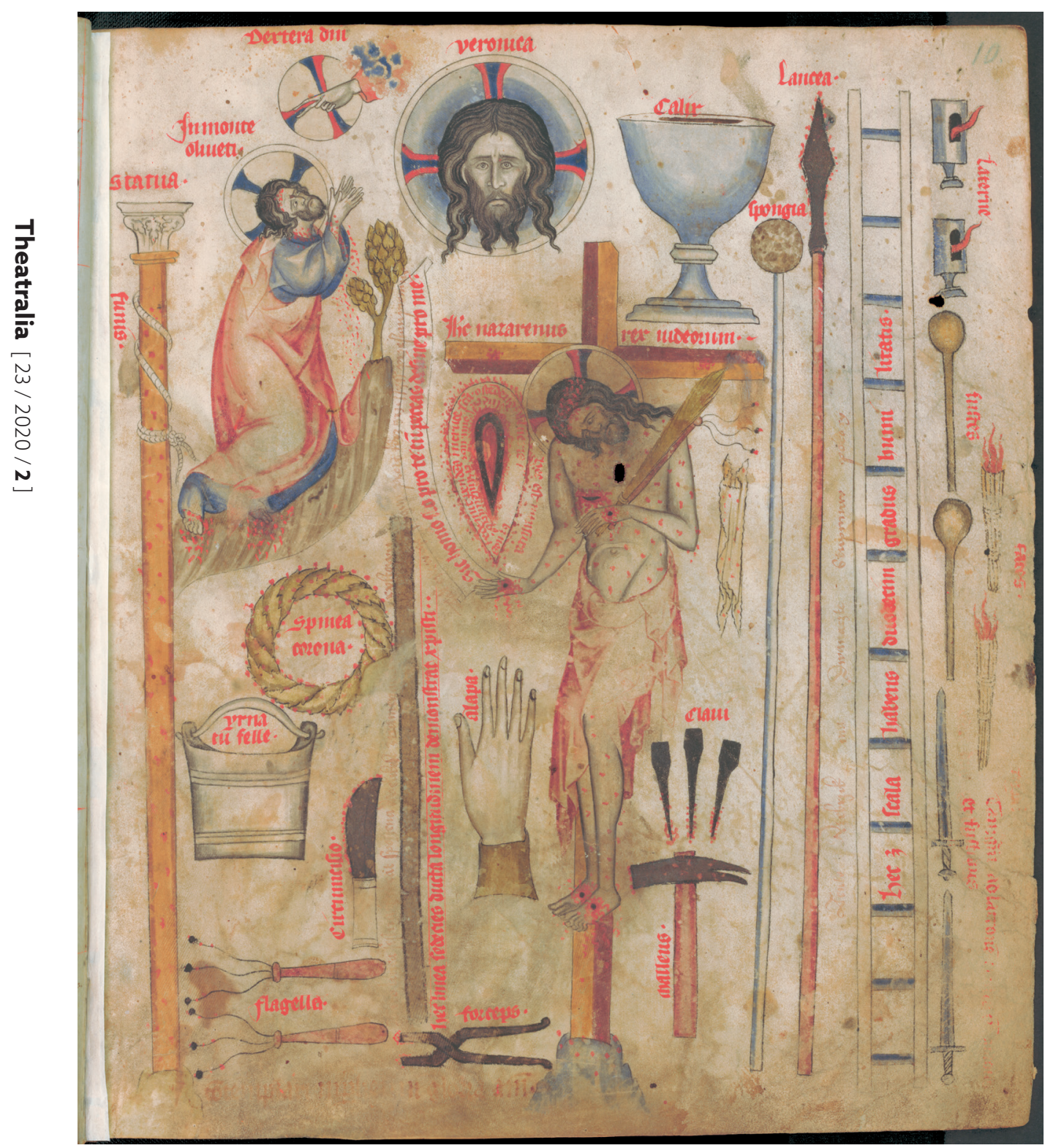

Fig. 3: Depiction of the arma Christi in the Passional of Abbesse Kunigunde, National Library of the Czech Republic, ms. XIV.A.17, fol. 10r. (c) National Library of the Czech Republic. 


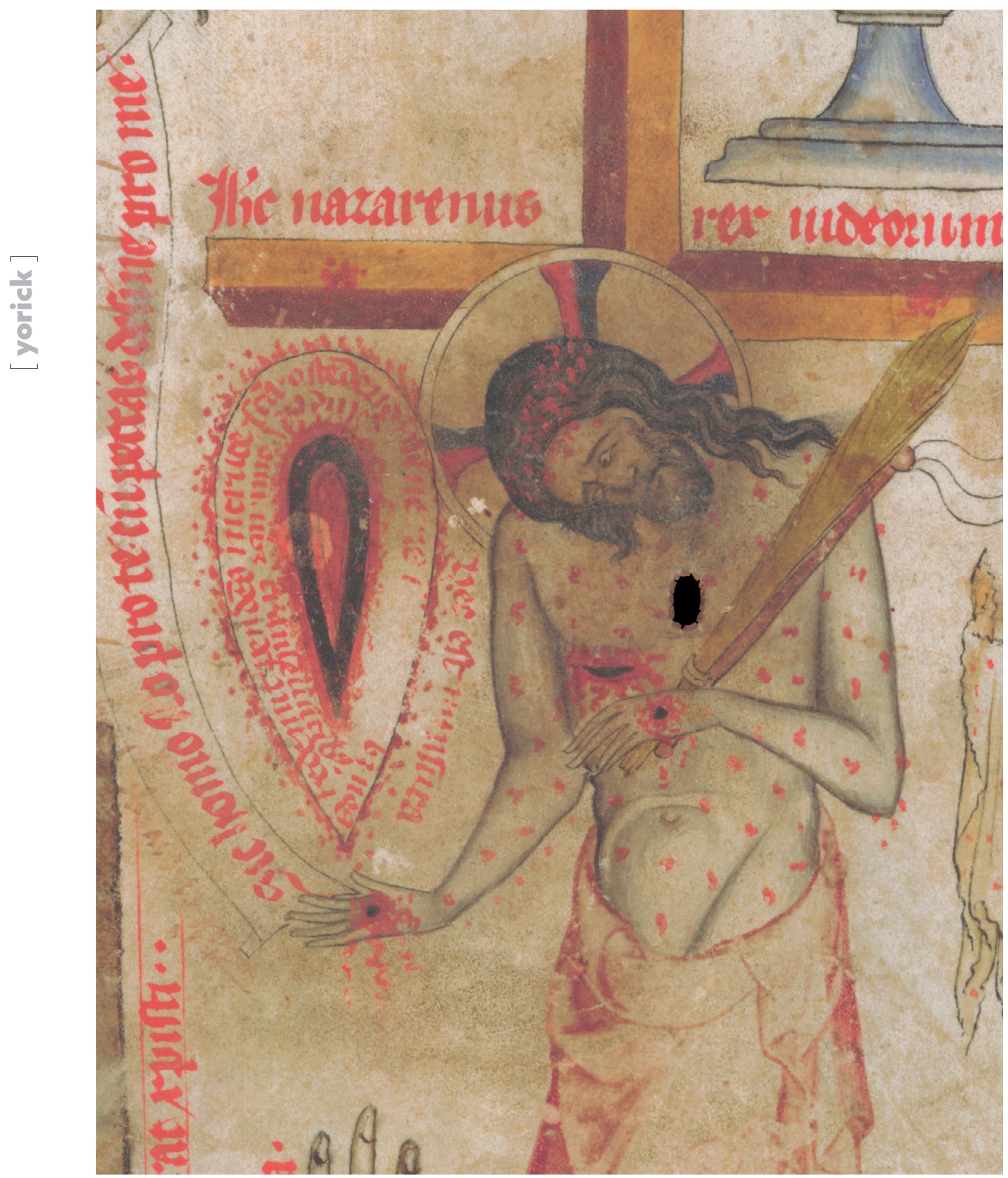

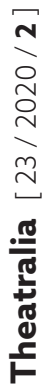

Fig. 4: Depiction of Christ's Side Wound in the Passional of Abbesse Kunigunde, detail. 
(BARTLOVÁ 2012: 153). This might have been the case of the Abbess Kunigunde alone or also other prominent members of the convent as well; priests entrusted with the spiritual care of the nuns likely participated in this form of veneration as well.

An obvious question is why and to what effect was the picture interacted with in this particular way. To address these points, the Side Wound, the most important of the wounds of Christ, must be considered from the feminine, one is even impelled to say gynaecological, perspective.

In the Christian tradition, the final stabbing of Jesus Christ in the side by the spear of a Roman soldier, usually referred to as a Side Wound, is sometimes known as the 'wound of love', as it was out of love that Jesus suffered for humankind. In a similar vein, it was often interpreted as the birth canal of the Christian church, which was purportedly born from Christ's side just as Eve came from the side of Adam. These metaphors may account for the way in which the wound was depicted in the Late Middle Ages - in a manner decidedly vaginal in appearance, as art historians have observed (see Fig. 5; cf. e.g. TAMMEN 2006; HOLLYWOOD 2016).

This peculiar depiction probably arouse from distinctly medieval, but also very generic, experiences and fantasies associating love, sex, pregnancy and childbirth with significant dogmatic concepts of the time. While deeply embedded in high medieval spirituality, this reverence for procreation might also strike many of us today as understandable and even quite appropriate. ${ }^{19}$

In actual performative practice, the vaginal representation of the Side Wound worked as a protective image, especially during childbirth. An example of an artifact used for this practice is a scroll from the $15^{\text {th }}$ century with five magic figures depicting the Five Wounds of Christ which is now in the British Museum. The paper scroll, which combines textual and pictorial talismans with schematic Passion imagery, measures more than a meter in length and was used during labour to protect the woman giving birth. One of the texts written on the scroll explains that it was not necessary to read the text of the artifact to execute its protective power - it was enough just to wrap it around the body of a woman for it to protect the mother and new-born child against evil powers that intended to harm them (BRILLIANT 2016). The devotional mechanism by which the talismanic object operated was that of sympathetic, or imitative magic. In this type of magical practice, the effect is ensured by the application of similia; for instance, a headache can be cured by offering a replica of head made of wax, wood or metal in the shrine of an appropriate saint, ideally John the Baptist (OBERHELMAN 2012: $8-9)$. In a similar vein, the vaginal side-wound was believed to be of assistance in the course of labour because of its obvious relation to procreation.

The devotional practice of kissing the Side Wound from the Passional of Abbess Kunigunde may have been informed by the same belief in the apotropaic function of the image, an association shown not only by the scroll but also by other objects decorated accordingly, namely rings. At the same time, the strong appeal to devotees to

19 For a detailed discussion of the topic, see (NEFF 1996: 262-267); for examples of objects depicting Christ's wound that were believed to have apotropaic power, especially during childbirth, see (BRILLIANT 2016). 


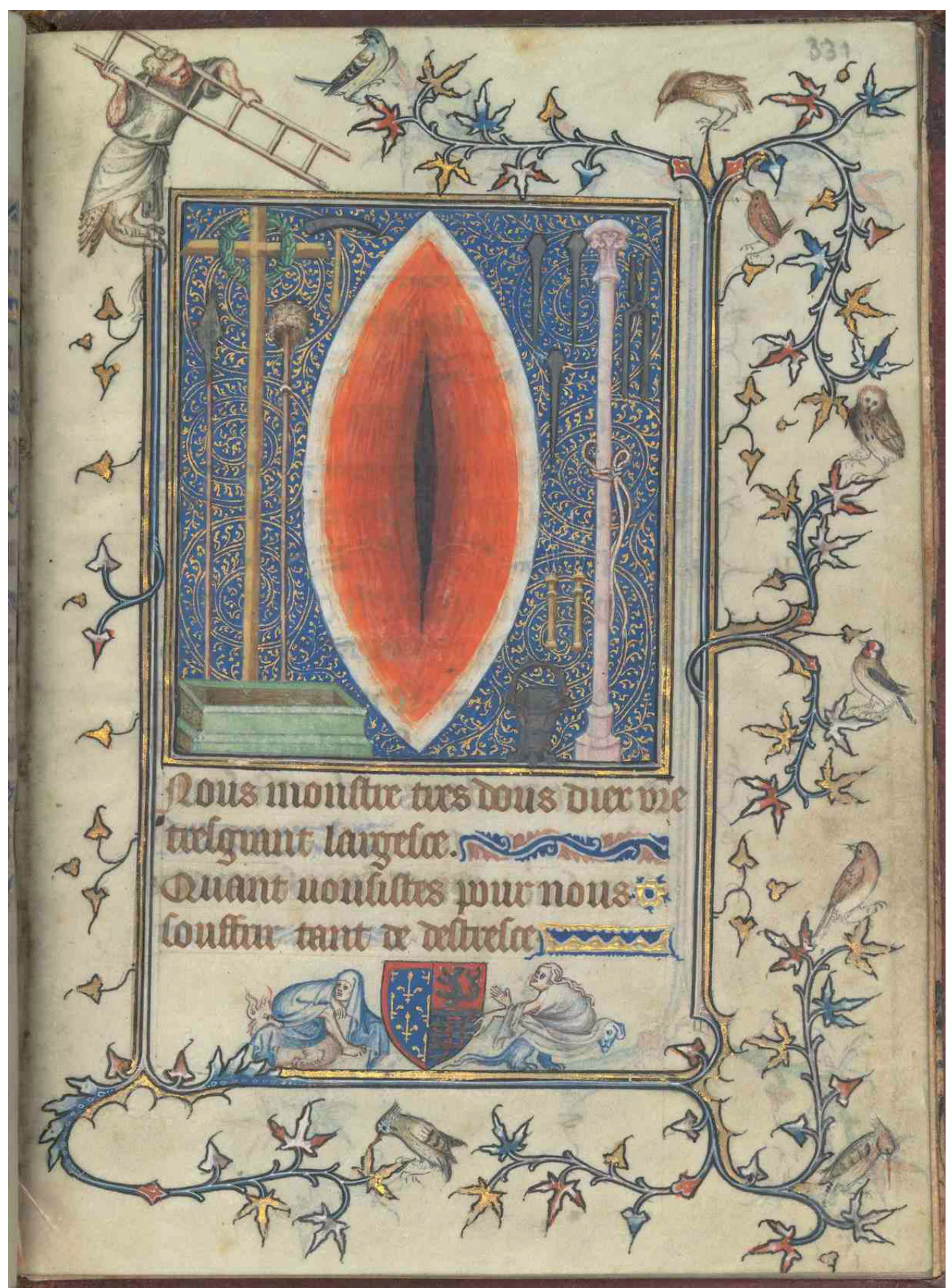

ָ̃

Fig. 5: Christ's Side Wound, Psalter of Bonne de Luxembourg, Jean Le Noir, circa 1349. Source: WikiCommons. 
make physical contact with the manuscript may be interpreted not only as a cognitive operation but also as a physical one in the performative sense: touching the picture of the holy object to one's own lips might have seemed a particularly operative bodily exercise to attain the 'as if' position demanded by Stanislavski in order for the actor to empathize fully with the characters - in this case the suffering Jesus Christ and Virgin Mary.

\section{Experiencing Social Elevation Through the Performance of Compassion(?)}

In place of a conclusion, I would like to suggest the possible political effects of performative practices similar to the ones described on the previous pages. Far from pertaining merely to the individual, the above-mentioned devotional acts had also certain consequences for the social life of the nuns and other female devotees who practiced affective devotion as a part of their spiritual exercises (cf. MCNAMER 2010: 25-57).

In a society where female gender was universally regarded as inferior to the male, women tended to be forced into socially and economically marginalized positions. They were perceived to enjoy comparatively less power than their male counterparts, even concerning their own bodies. As purported by Pierre Bourdieu, symbolic power always works, at least to some extent, through the control of other people's bodies (CONNEL and MEARS 2018). In that sense, medieval women were constantly disempowered by acts of everyday violence: from being forced to marry against their own will to being excluded from many substantial symbolic activities, for example - and most notably from presiding over the mass. ${ }^{20}$ I would argue, however, that devotional practices such as those presented here at least had a potential to empower, albeit temporarily, the women who undertook them.

Touching the birth roll or kissing the image of Christ's Side Wound, the female devotee adopted for a limited span of time the prominent role, usually occupied, by men of an individual 'in power' and 'with access to what is important'. More specifically, in manipulating these devotional objects, the female devotee was functionally elevated to the position of a man, as it was generally the man, a cleric, who was allowed the privilege of communicating directly with God through sacred objects.

Similarly, in adopting the position of the Virgin Mary, the devotee behaved 'as if' she were, even for the moment, the Virgin Mary herself. The ultimate paragon of female virtues, the Virgin Mary was constantly placed before medieval women to instruct them in appropriate female behaviour: patience, compassion, submission, chastity, etc. In a sort of subversive turn, in the above-mentioned acts of affective piety the female devotee becomes the Virgin not just metaphorically, but literally, experiencing what it feels like to embody the most important figure of Christianity after Jesus Christ himself. Fairly enough, this elevation of status may seem ephemeral, even insignificant, 
occurring only 'in the head' of the devotee, or difficult to corroborate. Nevertheless, besides the fact that thinking in itself can be understood as a performative act, ${ }^{21}$ this imagined elevation of the female devotee's social status might have also had very concrete and practical outcomes. If the woman succeeded in establishing herself as a true Bride of Christ (sponsa Christi) by practising particular devotional acts (including reading the tracts such as the Lament of the Virgin Mary), she was considered legally married to Christ and could not be forced into another, earthly, marriage (MCNAMER 2010: 32-53). This represented one of the most independent positions a woman might attain in medieval society, and the one some of the recipients of the Lament from the Passional established themselves in as fully vowed nuns dedicated to Christ - and to the order for the rest of their lives (in contrast to those members of the convent who lived there only temporarily before they were married, see note 2 ).

What I wanted to demonstrate by and large is that despite their generally unfavourable social position, medieval women actually did in fact possess means to elevate their social position, at least temporarily. Taking into consideration Bourdieu's (cit. from CONNEL and MEARS 2018) and Judith Butler's (1988) assertions about the processual nature of the constitution of such seemingly fixed (medieval) phenomena as gender and social status, it probably does not come as a surprise that the structural inferiority of women in medieval society was, or at least could be, subject to subversive negotiation. Among the various possibilities for a woman to uplift herself, a significant number of them consisted of performative practices related to the sphere of religious devotion, either private or public. On the more theatrical side of these practices we can find the mimetic performances of dramatized liturgy representing the characters of holy women (the three Marys, Mary Magdalene, female saints) as the paragons of virtue for the female audience - especially nuns and secular aristocrats to imitate and identify with. Although these performances may have been somewhat limited in impact, since the female characters were usually performed by male clerics, the female audience could in fact identify with the female characters intellectually. Nevertheless, a certain cognitive and emotional split must have remained present in this experience because of the representation of the female characters by ostensibly male bodies. ${ }^{22}$ In the performative devotional practices such as those described in this study, women were encouraged to take a step further and adopt the position of a Stanislavskian actor, experiencing through their own bodies what it was like to truly become the 'elevated one' in the person of the Virgin Mary. While reading, reciting or listening to the Lament of Virgin Mary, they were to imagine themselves 'as if' they were in her position, standing under the cross, weeping inconsolably, bending under the unbearability of the present moment, falling to their knees, prostrating themselves on the ground, beating their chests - even actually perform these acts with their bodies if they deemed it appropriate.

21 Cf. e.g. Austin's concept of performative utterance (AUSTIN 1962) and Welch's theory of the relation between reflectivity and performativity (WELCH 1981).

22 As was usually the case with religious theatre; however, Walter Ogden lists 23 nunneries across Europe where the female roles were enacted by women - the nuns from the respective convents (OGDEN 2002: 143). 
These, I believe, are performative mechanisms of social promotion similar to those which can be located in present phenomena such as theatre performed with young people in favelas, with war veterans or the victims of war conflicts. In all these cases, a performative bodily action based on the process of empathizing with oneself and one another seems to take an empowering effect on those members of the society who would otherwise be neglected and marginalized.

\section{Bibliography}

AUSTIN, John Longshaw. 1962. How to Do Things with Words. Oxford: Clarendon Press, 1962.

BAGNOLI, Martina (ed.). 2016a. A Feast for the Senses. Art and Experience in Medieval Europe. Baltimore: Walters Art Museum, 2016.

BAGNOLI, Martina. 2016b. Making Sense. In Martina Bagnoli (ed.). A Feast for the Senses. Art and Experience in Medieval Europe. Baltimore: Walters Art Museum, 2016: 17-30.

BARTLOVÁ, Milena. 2012. Skutečná př́tomnost. Středověký obraz mezi ikonou a virtuální realitou [The Real Presence. Medieval Picture Between Icon and Virtual Reality]. Praha: Argo, 2012.

BRILLIANT, Virginia. 2016. Items 64-68, Catalogue. In Martina Bagnoli (ed.). A Feast for the Senses. Art and Experience in Medieval Europe. Baltimore: Walters Art Museum, 2016: 200-203.

BUTLER, Judith. 1988. Performative Acts and Gender Constitution: An Essay in Phenomenology and Feminist Theory. Theatre Journal 40 (1988): 4: 519-531.

Connel, Catherine and Ashley Mears. 2018. Bourdieu and the Body. In Thomas Medvetz and Jeffrey J. Sallaz (eds.). The Oxford Handbook of Pierre Bourdieu. New York: Oxford University Press, 2018: 561-576.

CONWAY, Charles Abbot. 1976. The Vita Christi of Ludolph of Saxony and Late Medieval Devotion Centred on the Incarnation: A Descriptive Analysis. Salzburg: Institut für Englische Sprache und Literatur, Universität Salzburg, 1976.

COOPER, Lisa H. and Andrea DENNY-BROWN (eds.). 2014. The Arma Christi in Medieval and Early Modern Material Culture. Surrey/Burlington: Ashgate, 2014.

HAMBURGER, Jeffrey F. 2011. Bloody Mary: Traces of the peplum cruentatum in Prague and in Strasbourgh. In Zoë Opačić and Achim Timmermann (eds.). Image, Memory and Devotion: Liber Amicorum Paul Crossley. Turnhout: Brepols, 2011: 1-34.

HOLLYWOOD, Amy. 2016. 'The Glorious Slit'. Irigaray and the Medieval Devotion to Christ's Side Wound. In Amy Hollywood. Acute Melancholia and Other Essays: Mysticism, History and the Study of Religion. New York/Chichester: Columbia University Press, 2016: 171-188.

HRBÁČOVÁ, Jana (ed.). 2015. Křivákova pieta. Restaurováni 2005/2013-2014 [Křivák’s Pieta. Renovation 2005/2013-2014]. Olomouc: Muzeum umění Olomouc, 2015.

IOHANNIS DE CAULIBUS. 1997. Meditationes vitae Christi, olim S. Bonaventuro attributae. Ed. by Mary Stallings-Taney. Turnhout: Brepols, 1997.

MCNAMER, Sarah. 2010. Affective Meditation and the Invention of Medieval Compassion. Philadelphia: University of Pennsylvania Press, 2010.

Ms. XIV A 16, National Library Prague, Passionale quod dicitur Cunegundis abbatissae, the planct on fol. $11 \mathrm{r}-17 \mathrm{v}$, accessible from www.manuscriptorium.com [cited 28. 4. 2020]. 
NEFF, Amy. 1998. The Pain fo Compassio: Mary's Labor at the Foot of the Cross. The Art Bulletin 80 (1998): 2: 254-273.

NEUBAUER, Zdeněk. 2011. O pokladu v srdci Evropy: Jedna z cest $k$ duchovnimu bohatstvi obrazů Vyšebrodského oltárére [On a Treasure in the Heart of Europe: One of the Ways to the Spiritual Wealth of the 'Vyšebrodský oltáŕ' Desk Paintings]. Praha: Malvern, 2011.

OBERHELMAN, Steven M. 2012. Pharmacological and Non-Pharmacological Treatment of Headaches in Cretan Healing Manuals. ATINER'S Conference Paper Series, No: MDT2012-0009, Athens 2012, accessible from https://www.atiner.gr/papers/MDT2012-0009.pdf/ [cited 14. 4. 2019].

PEŠINA, Jaroslav. 1982. Der Hohenfurther Meister. Prag: Odeon, 1982.

POLÁČKOVÁ, Eliška. 2021. Marian Laments From Medieval Bohemia. Performing Suffering and Redemption Through Compassion. European Medieval Drama, in print.

RUDY, Gordon. 2002. The Mystical Language of Sensation in the Latter Middle Ages. New York: Routledge, 2002.

RUDY, Gordon. 2018. Touching the Book Again: The Passional of Abbess Kunigunde of Bohemia. In Patrizia Carmassi and Gia Toussaint (eds.). Codex und Material. Wolfenbütteler Mittelalter-Studien 34. Wiesbaden: Harrassowitz Verlag, 2018: 247-257.

SHARROCK, Wes and Graham Button. 1991. The Social Actor: Social Action in Real Time. In Graham BUTTON (ed.). Ethnomethodology and the Human Sciences. Cambridge: Cambridge University Press, 1991: 137-175.

SHOEMAKER, Stephen J. Mary at the Cross, East and West: Maternal Compassion and Affective Piety in the Earliest Life of the Virgin and the High Middle Ages. The Journal of Theological Studies 62 (2001): 570-606.

SOFER, Andrew. 2003. The Stage Life of Props. Ann Arbor: The University of Michigan Press, 2003.

ŠRONĚK, Michael. 2009. The Veil of the Virgin Mary: Relics in the Conflict Between Roman Catholics and Utraquists in Bohemia in the Fourteenth and Fifteenth Centuries. Uměni 57 (2009): 118-139.

STANISLAVSKI, Konstantin. 2003 [1936]. An Actor Prepares. New York: Routledge, 2003.

TAMMEN, Silke. 2006. Blick und Wunde - Blick und Form: zur Deutungsproblematik der Seitenwunde Christi in der spätmittelalterlichen Buchmalerei. In Kristin Marek (ed.). Bild und Körper im Mittelalter. Munich: Wilhelm Fink, 2006: 85-114.

URBÁNKOVÁ, Emma and Karel STEJSKAL (eds.). Pasional přemyslovny Kunhuty - Passionale abbatissae Cunegundis. Praha: Odeon, 1975.

VILIKOVSKÝ, Ján. 1948. Písemnictvi českého středověku [Czech Medieval Literature]. Praha: Universum, 1948.

WALSH-BOWERS, Richard. 2006. A Theatrical Acting Perspective on the Dramaturgical Metaphor and the Postmodern Self. Theory E P Pychology 16 (2006): 5: 661-690.

WARD, Jennifer. 2002. Women in Medieval Europe: 1200-1500. New York: Routledge, 2002.

WELCH, Cyril. 1981. A Preface to Reading. Philosophy E Rhetoric 14 (1981): 1: 31-50. 


\section{Mgr. Eliška Poláčková, Ph.D.}

Katedra divadelních a filmových studií, Filozofická fakulta,

Univerzity Palackého v Olomouci,

Univerzitní 3, 77900 Olomouc

eliska.polackova@upol.cz

Eliška Poláčková is Assistant Professor at the Department of Theatre and Film Studies, Palacký University Olomouc; and postdoctoral researcher at the Centre of Classical Studies (Czech Academy of Sciences, Prague). Her professional interests comprise Classical, especially Roman Theatre and Drama, Medieval Theatre and Performance Culture, and Theatre Translation. 
